\title{
Inactivation of two haemolytic toxin genes in Aeromonas hydrophila attenuates virulence in a suckling mouse model
}

\author{
Christopher Y. F. Wong, ${ }^{1} \dagger$ Michael W. Heuzenroeder ${ }^{2}$ \\ and Robert L. P. Flower ${ }^{1}$ \\ Author for correspondence: Christopher Y. F. Wong. Tel: +6188303 3849. Fax: +61883034362. \\ e-mail: cwong@microb.adelaide.edu.au
}

1 School of Pharmacy and Medical Sciences, University of South Australia, Adelaide, South Australia 5000, Australia

2 Infectious Diseases Laboratories, Institute of Medical and Veterinary Science, Adelaide, South Australia 5000, Australia
The contribution of two unrelated Aeromonas hydrophila $\beta$-haemolytic toxins to virulence was assessed in a suckling mouse model. The first haemolysin gene, isolated from an A. hydrophila A6 cosmid bank, encoded a potential gene product of 621 amino acids and a predicted molecular size of $69.0 \mathrm{kDa}$. The inferred amino acid sequence showed $89 \%$ identity to the AHH1 haemolysin of A. hydrophila ATCC 7966, and $51 \%$ identity to the HlyA haemolysin of Vibrio cholerae El Tor strain 017. The second haemolysin gene (designated aerA), which encodes aerolysin, a pore-forming toxin, was partially cloned by PCR for the purpose of mutant construction. This PCR product was a $1040 \mathrm{bp}$ fragment from the C-terminal region of aerA. It is proposed that the $69.0 \mathrm{kDa} \mathrm{V}$. cholerae-HlyA-like haemolysin gene be termed hlyA to contrast with the aerA terminology for the aerolysin. A suicide vector was used to inactivate both the hlyA and aerA genes in A. hydrophila A6. When assessed in the suckling mouse model, only the hlyA aerA double mutant showed a statistically significant reduction in virulence - a 20-fold change in $L_{50}$ (Scheffe test, $P<0.05$ ). Cytotoxicity to buffalo green monkey kidney cell monolayers and haemolysis on horse blood agar were eliminated only in the hlyA aerA double mutants. This is the first report of cloning and mutagenesis of two unrelated haemolytic toxin genes in the same strain of a mesophilic aeromonad. For A. hydrophila, a two-toxin model provides a more complete explanation of virulence.

Keywords: Aeromonas hydrophila, aerolysin, haemolysin, suckling mouse model, virulence

\section{INTRODUCTION}

The role of toxins as virulence factors in disease resulting from infection of the gut by Gram-negative organisms is well accepted. Aeromonas hydrophila is a ubiquitous Gram-negative organism of the aquatic environment (Okpokwasili, 1991; Alonso et al., 1994; Papapetropoulou \& Rodopoulou, 1994; Rhodes \&

†Present address: Department of Microbiology and Immunology, Medical School South, The University of Adelaide, Adelaide, South Australia 5005, Australia.

Abbreviation: BGMK, buffalo green monkey kidney.

The GenBank accession number for the $2265 \mathrm{~kb}$ DNA fragment encoding hlyA on pCWH3 is U81555.
Kator, 1994; Sugita et al., 1995) which has been implicated as a causative agent of human diarrhoea (Burke et al., 1983; Agger et al., 1985; Deodhar et al., 1991; Delamorena et al., 1993; Ogunsanya et al., 1994; Rautelin et al., 1995; Utsalo et al., 1995). For aeromonads, the use of different assays for the detection of toxins has resulted in complex and confusing nomenclature. The majority of A. hydrophila diarrhoeal isolates are $\beta$-haemolytic and produce cytotoxins. Two cloned and sequenced haemolytic toxin genes of $A$. hydrophila are those encoding AHH1 haemolysin (Hirono \& Aoki, 1991) and aerolysin (Howard et al., 1987). These haemolytic toxins have only $18 \%$ homology and are distinct (Hirono \& Aoki, 1991).

The AHH1 haemolysin consists of 577 amino acid residues with a molecular mass of $63.7 \mathrm{kDa}$. The gene 
Table 1. Strains and plasmids used or constructed in this study

\begin{tabular}{|c|c|c|}
\hline Strain/plasmid & Relevant characteristics & Source/reference \\
\hline \multicolumn{3}{|l|}{$\begin{array}{l}\text { A. hydrophila } \\
\text { strains }\end{array}$} \\
\hline ATCC 7966 & Wild-type; $A p^{r}$ & Hirono \& Aoki (1991) \\
\hline Ah65 & Wild-type; $A p^{r}$ & Howard et al. (1987) \\
\hline A6 & Wild-type; $A p^{r}$ & Atkinson \& Trust $(1980)$ \\
\hline $\mathrm{A} 6 \mathrm{H}$ & blyA EagI deletion mutation & This study \\
\hline A6A & $\operatorname{aer} A \mathrm{Km}^{\mathrm{r}}$ insertion mutant & This study \\
\hline A6HA & bly $A$ aer $A$ mutant & This study \\
\hline \multicolumn{3}{|l|}{ Plasmids } \\
\hline pGEM-T & $A p^{r}$ cloning vector & Promega \\
\hline pUC18K & pUC18 with the non-polar $a p h A-3 \mathrm{Km}^{\mathrm{r}}$ resistance cassette & Menard et al. (1993) \\
\hline pCACTUS2 & $\begin{array}{l}\text { Suicide } \mathrm{Cm}^{\mathrm{r}} \text { cloning vector, contains } s a c B \text { and has a temperature- } \\
\text { sensitive origin of replication }\end{array}$ & $\begin{array}{l}\text { C. Clark and others } \\
\text { (unpublished) }\end{array}$ \\
\hline pCWH1 & $\begin{array}{l}\text { pHC79 carrying an approximately } 40 \mathrm{~kb} \text { fragment of } A \text {. bydrophila A6 } \\
\text { genomic DNA }\end{array}$ & This study \\
\hline pCWH2 & SphI stepwise deletion of pCWH1 & This study \\
\hline pCWH3 & ClaI stepwise deletion of $\mathrm{pCWH} 2$ & This study \\
\hline pCWH4 & pCWH3 with an 857 bp EagI fragment of blyA deleted & This study \\
\hline pCWH5 & $\begin{array}{l}\text { pCACTUS2 carrying the Smal fragment of pCWH4 containing the } \\
\text { deletion mutation }\end{array}$ & This study \\
\hline pCWA1 & pGEM-T carrying the 1040 bp PCR product derived from aer $A$ & This study \\
\hline pCWA2 & pCWA1 carrying a $\mathrm{Km}^{\mathrm{r}}$ gene in the $S m a \mathrm{I}$ site & This study \\
\hline pCWA3 & pCACTUS2 carrying the BamHI fragment of pCWA2 & This study \\
\hline
\end{tabular}

encoding this haemolysin was cloned and sequenced from A. hydrophila ATCC 7966 (Hirono \& Aoki, 1991). The gene encoding a similar haemolysin, designated ASH4, was cloned from Aeromonas salmonicida 17-2 by Hirono \& Aoki (1993). The ASH4 haemolysin gene encodes a 578 amino acid polypeptide with a molecular mass of $64.4 \mathrm{kDa}$ which was $84 \%$ homologous to the AHH1 haemolysin.

Aerolysin consists of 463 amino acid residues with a molecular mass of $53.8 \mathrm{kDa}$. The gene encoding aerolysin was originally cloned and sequenced from $A$. bydrophila Ah65, a fish isolate (Howard et al., 1987). Xray crystallography studies showed that the haemolytic property of this toxin was mediated by pore formation in the erythrocyte cell membranes when seven of the aerolysin peptides come together to form a barrel structure (Parker et al., 1994, 1996). In addition to its cytolytic activity to red cells and various tissue cell lines, aerolysin possesses enterotoxic activity (Rose et al., 1989).

A. bydrophila A6, a diarrhoeal isolate, is lethal in suckling mice when administered by gavage (Wong et al., 1996). The data presented in this paper show that strain A6 produces a $V$. cholerae-HlyA-like haemolysin in addition to aerolysin and it is the combined effect of both haemolytic toxins that causes the $\beta$-haemolysis on horse blood plates and the cytotoxicity to buffalo green monkey kidney (BGMK) cell lines, and that contributes to virulence in the suckling mouse assay.

\section{METHODS}

Bacterial strains and plasmids. Bacterial isolates and plasmids obtained or constructed in this study are listed in Table 1. Bacteria were cultivated in Luria broth or on Columbia agar. When required, defibrinated horse blood $(5 \%)$ was added to the Columbia agar (HBA). Antibiotics were added to broth and solid media as described previously (Wong et al., 1997). Minimal M9 medium (Miller, 1972) was supplemented with $2 \mu \mathrm{g}$ vitamin $B_{1} \mathrm{ml}^{-1}, 2 \%$ glucose and/or $6 \%$ sucrose for the selection of resolved plasmids during allelic exchange in $A$. bydrophila A6.

Molecular methods. The preparation of chromosomal and plasmid DNA, construction of an A. hydrophila A6 cosmid bank, recombinant DNA techniques, and nucleotide sequencing and analysis have been described elsewhere (Wong et al., 1997). Recombinant DNA clones containing the haemolysin gene of $A$. hydrophila were screened for $\beta$ haemolysis on HBA supplemented with ampicillin. The protocol for the amplification of the aer $A$ and $b l y A$ genes from A. bydrophila isolates was adapted from Wong et al. (1997).

Allelic exchange. The method of allelic exchange for the aer $A$ and/or the blyA genes in A. bydrophila was performed using the suicide vector pCACTUS2 and has been described previously (Wong et al., 1997).

Suckling mouse model. Preparation of feeding inocula, infection of suckling mice and $\mathrm{LD}_{50}$ determinations with $A$. bydrophila $\mathrm{A} 6$ and its mutants and the determination of accumulation of fluid in the gut (FA ratio) were followed according to the method of Wong et al. (1996). The FA ratio was expressed as the weight of the gut $(\mathrm{mg})$ over the weight of the remaining carcass $(\mathrm{g})$. The arbitrary cut-off value for 
positive FA ratio is $80 \mathrm{mg} \mathrm{g}^{-1}$. An FA ratio of $49 \pm 4 \mathrm{mg} \mathrm{g}^{-1}$ was considered as negative for accumulation of fluid in the intestine according to the criteria of Wong et al. (1996).

Statistical analysis. The one-way analysis of variance (ANOVA) and the Scheffe test were performed using the BMDP7D statistical software (BMDP Statistical Software, CA, USA).

Assay for cytotoxicity. The assay for cytotoxicity was performed with modifications from Wong et al. (1996). Briefly, $100 \mu \mathrm{l}$ serial doubling dilutions (2-2048) of filter-sterilized culture supernatants of overnight bacterial cultures were added to a BGMK cell monolayer and incubated for $18 \mathrm{~h}$ at $37^{\circ} \mathrm{C}$ in a humidified chamber. Cytotoxic effects on the monolayer were quantified using the crystal violet staining method of Matthews \& Neale (1987).

Electrophoresis, and Western and Southern blot analysis. DNA was separated using agarose gel electrophoresis and visualized after staining in ethidium bromide. When required, the separated DNA was transferred onto nylon filters according to the method of Southern (1975). The nylon filter was probed with digoxigenin-labelled $1040 \mathrm{bp}$ aer $A$ PCR products or $597 \mathrm{bp}$ hly $A$ PCR product for $18 \mathrm{~h}$ at $42^{\circ} \mathrm{C}$. Removal of residual unbound probes and detection of the DNA fragment using the digoxigenin detection system are described elsewhere (Wong et al., 1997).

\section{RESULTS}

\section{Cloning and sequencing of hlyA and aerA}

A single cosmid, designated pCWH1, which was $\beta$ haemolytic on HBA was identified in a bank of 250 cosmids following cloning of A. hydrophila A6 Sau3AIdigested DNA into cosmid vector pHC79. Stepwise deletion on pCWH1 using enzymes ClaI and $S p h \mathrm{I}$ indicated that the gene for the expression of the haemolysin was located on a $2 \mathrm{~kb} C l a \mathrm{I}-S p h \mathrm{I}$ fragment. The DNA sequence of the insert of the resulting plasmid, $\mathrm{pCWH} 3$, was determined and the restriction map is shown in Fig. 1.

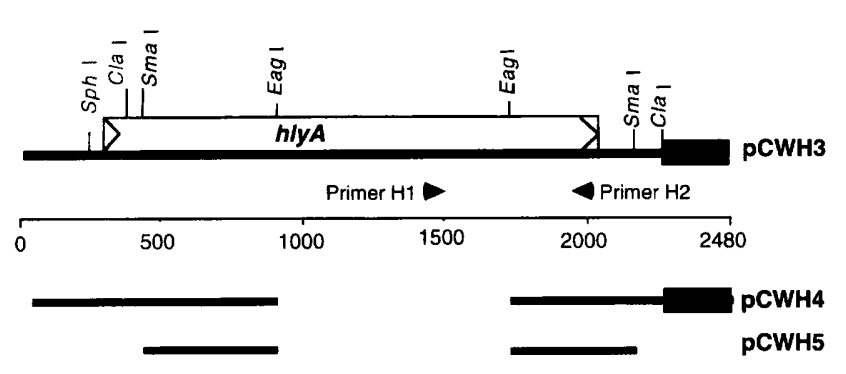

Fig. 1. Restriction endonuclease cleavage pattern, DNA labelling, and deletion analysis of plasmid pCWH3. The bold box on the right end of pCWH3 corresponds to residual cosmid vector pHC79 (Hohn \& Collins, 1980). Primers H1 (5'-GGC CGG TGG CCC GAA GAT ACG GG-3') and H2 (5'-GGC GGC GCC GGA CGA GAC GGG-3') were used in a PCR reaction to detect a 597 bp hlyA DNA fragment in a PCR survey on $A$. hydrophila strains ATCC 7966 and Ah65. A digoxigenin-labelled Smal probe was used in Southern blot analysis to confirm $A$. hydrophila chromosomal arrangements. pCWH4 and pCWH5 are the mutant constructs made by deletion of an $857 \mathrm{bp}$ Eagl fragment of the hlyA gene.
For aer $A$, a $1040 \mathrm{bp}$ fragment in the $3^{\prime}$ region of the $A$. bydrophila aerA gene (Fig. 2) was amplified using primers A3 and A4. The purified PCR product was then cloned into pGEM-T (Promega) to yield pCWA1.

\section{Sequence analysis}

The nucleotide sequence of the ClaI-SphI fragment of pCWH3 revealed an ORF (nt 172-2037) encoding a potential gene product comprising 621 amino acids with a molecular size of $69.0 \mathrm{kDa}$. The putative promoter regions of this ORF showed $83 \%$ identity $(5 / 6$ nucleotides) with consensus Escherichia coli -10 and -35 sequences. In addition, a putative ribosomebinding site (Shine \& Dalgarno, 1974), cAAGGAGaT, was found seven bases upstream from the ATG start codon. Downstream from the termination codon at position 2037 is an area of dyad symmetry (nt 2063-2090) with a $\Delta G$ value of $-18.90 \mathrm{kcal} \mathrm{mol}^{-1}$ $\left(-79.38 \mathrm{~kJ} \mathrm{~mol}^{-1}\right)$ which may act as a transcriptional attenuator. According to the criteria of von Heijne (1986), this ORF contains a putative signal peptide with putative cleavage sites between amino acids 20 and 21 and possibly 30 and 31 .

\section{Amino acid sequence identity and similarity}

In this paper, the ORF encoding the 621-amino-acid protein is referred to as bly $A$. The inferred amino acid sequence of HlyA showed $85 \%$ identity to the AHH1 haemolysin of A. bydrophila ATCC 7966 (Hirono \& Aoki, 1991), $75 \%$ identity to the ASH4 haemolysin of $A$. salmonicida 17-2 (Hirono \& Aoki, 1993) and 51\% identity to the HlyA haemolysin of $V$. cholerae El Tor strain $\mathrm{O} 17$ (Alm et al., 1988). blyA is therefore a distinct allele of this gene in Aeromonas.

\section{Inactivation of the $h / y A$ and aerA genes}

The construction of the $A$. bydrophila blyA deletion mutant is shown in Fig. 1. Briefly, the 857 bp EagI DNA fragment of the blyA gene in pCWH3 was deleted and the resulting $5943 \mathrm{bp}$ fragment was recircularized to form pCWH4. The SmaI DNA fragment of pCWH4 containing the Aeromonas DNA flanking the deleted $857 \mathrm{bp}$ fragment was then cloned into the Smal-digested ends of the suicide plasmid pCACTUS2, yielding pCWH5. pCWH5 was then transferred by conjugation to A. bydrophila A6. The deletion mutant was designated $\mathrm{A} 6 \mathrm{H}$. Southern blot analysis of the A6H SmaI chromosomal digest confirmed the predicted chromosomal rearrangement in the A. hydrophila A6 genome (Fig. 3).

The process used to construct the A. hydrophila aerA insertionally inactivated mutant is illustrated in Fig. 2. An 850 bp non-polar aphA-3 cassette with a kanamycin resistance marker from vector $\mathrm{pUC18K}$ (Menard et al., 1993) was inserted into the SmaI site within the aerA gene of pCWA1 to yield pCWA2. The BamHI fragment of $\mathrm{pCWA} 2$ containing the kanamycin cartridge 


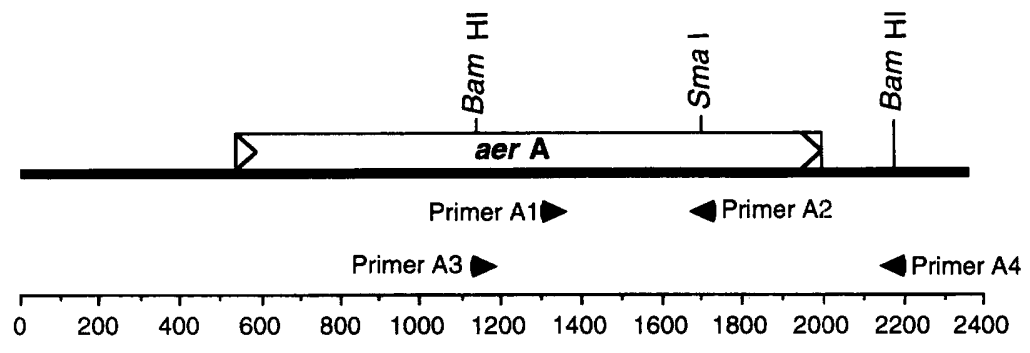

PCWA1

(in PGEM T)

PCWA2

(in PGEM T)
8

PCWA3 (b)

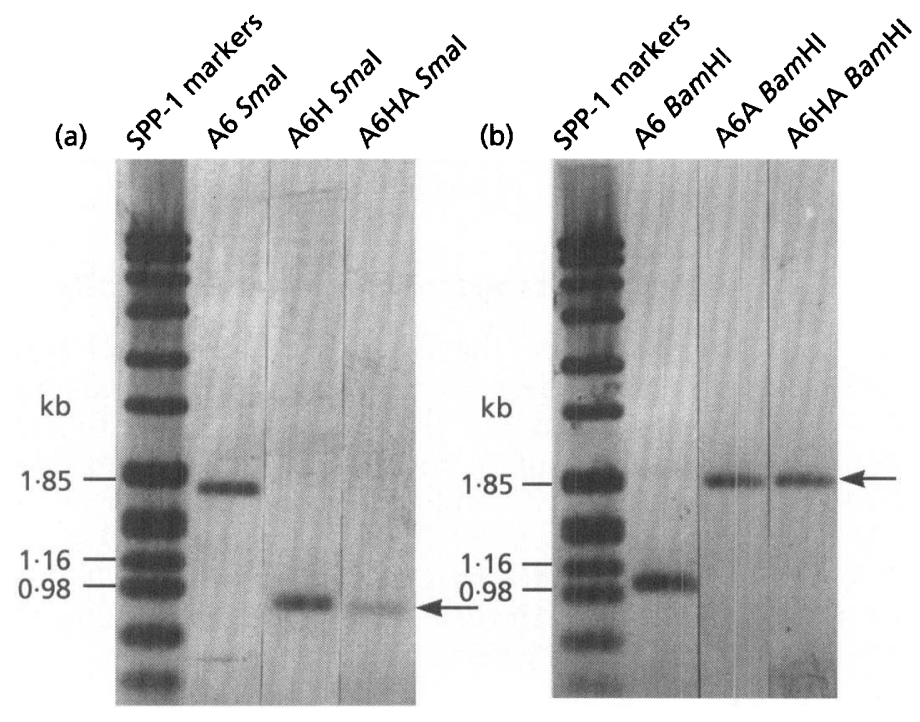

Fig. 2. Restriction endonuclease cleavage pattern, DNA labelling, and insertion analysis of the published aerolysin DNA sequence (Howard et al., 1987). The arrows in the aerA box indicate the direction of transcription. Primers A1 (5'-GCC TGA GCG AGA AGG T-3') and A2 (5'-CAG TCC CAC CCA CTT $C-3^{\prime}$ ) were used in PCR to detect a 416 bp DNA fragment in a PCR survey on $A$. hydrophila strains ATCC 7966 and Ah65. A digoxigenin-labelled $1040 \mathrm{bp}$ PCR product created by primers $A 3$ (5'-CGC CTA TAA CCT GGA TCC CGA C-3') and A4 (5'-CTG ATC AGG TTC CAC GGA TCC-3') was used as a probe in Southern blot analysis to confirm $A$. hydrophila chromosomal arrangements. The triangle in pCWA2 and pCWA 3 indicates the Smal site where the non-polar kanamycin $\left(\mathrm{Km}^{\mathrm{l}}\right)$ cartridge was inserted.

Fig. 3. Southern blot analysis of $h l y A(A 6 H)$, aerA (A6A) and hlyA aerA (A6HA) mutants. The arrows indicate the confirmed chromosomal rearrangement. (a) Smaldigested chromosomal DNAs were probed with digoxigenin-labelled Smal fragment DNA of pCWH3. The $1.8 \mathrm{~kb}$ band in A6 Smal was replaced by a $0.9 \mathrm{~kb}$ band in $\mathrm{A} 6 \mathrm{H}$ and $\mathrm{A} 6 \mathrm{HA}$ as a result of the $857 \mathrm{bp}$ deletion during the making of the deletion construct. (b) BamHI-digested chromosomal DNAs were probed with digoxigenin-labelled $1040 \mathrm{bp}$ aerA PCR product. The $0.9 \mathrm{~kb}$ band in $A 6$ $B a m H I$ was replaced by a $1.8 \mathrm{~kb}$ band in $A 6 \mathrm{~A}$ and $A 6 \mathrm{HA}$ as a result of the insertion of the kanamycin resistance cartridge.

Table 2. Virulence properties of $A$. hydrophila A6 mutants

\begin{tabular}{|llcc|}
\hline Strain & Mean $\mathrm{LD}_{50}{ }^{*}$ & & \\
\hline $\mathrm{A} 6$ & $6.3 \times 10^{7}(n=5)$ & ++ & 1024 \\
$\mathrm{~A} 6 \mathrm{H}$ & $4.8 \times 10^{7}(n=2)(P>0.05)$ & ++ & 1024 \\
$\mathrm{~A} 6 \mathrm{~A}$ & $6.6 \times 10^{8}(n=2)(P>0.05)$ & + & 8 \\
A6HA & $1.4 \times 10^{9}(n=3)(P<0.05)$ & 0 & $<4$ \\
\hline
\end{tabular}

* Numbers in parentheses indicate the number of times $(n)$ the $\mathrm{LD}_{50}$ was determined. The $P$ values were determined from the Scheffe test.

$\dagger \beta$-Haemolysis was observed as a transparent zone surrounding a bacterial colony on HBA following incubation at $30^{\circ} \mathrm{C}$ for $18 \mathrm{~h}$. ++ , Strong $\beta$-haemolysis; + , weak $\beta$-haemolysis; 0 , no $\beta$-haemolysis.

$\ddagger$ Cytotoxicity was expressed as titres with $<4$ indicating undetectable cytopathic effects.

with flanking Aeromonas DNA was then cloned into the BamHI-digested pCACTUS2 to yield plasmid pCWA3. The mutant construct was then transferred by conjugation to A. hydrophila A6. The insertion mutant was designated A6A. Southern blot analysis of the A6A
Bam HI chromosomal digest confirmed the predicted chromosomal rearrangement in the A. bydrophila A6 genome (Fig. 3). Similarly, pCWA3 was also used in the construction of the blyA aerA double mutant in $A$. bydrophila $\mathrm{A} 6 \mathrm{H}$ to yield A6HA. Southern blot analysis 
of the A6HA Smal and BamHI chromosomal digest confirmed the predicted chromosomal rearrangements in the A. bydropbila A6 genome (Fig. 3). In addition, both $\mathrm{A} 6 \mathrm{~A}$ and $\mathrm{A} 6 \mathrm{HA}$ were resistant to kanamycin, suggesting that the $5^{\prime}$ ribosome-binding site, start codon and translational reading frame of the cassette spliced in-frame with the $3^{\prime}$ end of the disrupted gene.

\section{Virulence of the $A$. hydrophila mutants in the suckling mouse model}

To investigate whether the $A$. bydrophila mutants were attenuated, strains $\mathrm{A} 6 \mathrm{H}, \mathrm{A} 6 \mathrm{~A}$ and $\mathrm{A} 6 \mathrm{HA}$ were assessed for virulence in suckling mice. All $\mathrm{LD}_{50}$ determinations were performed at least twice and compared with the $\mathrm{LD}_{50}$ of wild-type A6 (Table 2). Statistical analysis of the $\mathrm{LD}_{50}$ results for all four strains showed that the results were significantly different (ANOVA, $P=0 \cdot 017$ ). This difference was only apparent between A6 and A6HA (Scheffe, $P>0.05$ ), showing that the 20 -fold increase in $\mathrm{LD}_{50}$ was statistically significant. In the negative control group, mice administered $48 \mathrm{LD}_{50}$ of $65^{\circ} \mathrm{C}$ heat-killed wild-type A6 did not show any ill-effects during the course of the experiment. In the positive control group, mice administered $48 \mathrm{LD}_{50}$ of $A$. hydrophila $\mathrm{A} 6$ died within $9 \mathrm{~h}$ post-infection.

To determine if the mice administered $48 \mathrm{LD}_{50}$ of $\mathrm{A} 6 \mathrm{HA}$ died as a result of fluid accumulation in the gut, the FA ratio for 10 infected mice was determined at $9 \mathrm{~h}$ postinfection. As a positive control, the FA ratio for two surviving mice administered $48 \mathrm{LD}_{50}$ of wild-type $\mathrm{A} 6$ was $89 \mathrm{mg} \mathrm{g}^{-1}$. Mice administered $48 \mathrm{LD}_{50}$ of A6HA yielded a mean FA ratio of $49 \mathrm{mg} \mathrm{g}^{-1}$, a result similar to negative control mice administered broth only as demonstrated by Wong et al. (1996). Autopsy of mice infected with $48 \mathrm{LD}_{50}$ of wild-type A6 demonstrated extensive accumulation of fluid in the gut whereas mice administered $48 \mathrm{LD}_{50}$ of A6HA showed no pathological changes (data not shown).

\section{Biological activity of the $\boldsymbol{A}$. hydrophila mutants}

To investigate whether the A. hydrophila haemolytic toxins are cytotoxins, the culture supernatants of $A 6$, $\mathrm{A} 6 \mathrm{H}, \mathrm{A} 6 \mathrm{~A}$ and $\mathrm{A} 6 \mathrm{HA}$ were analysed for cytotoxicity to the BGMK cell monolayer and the results were expressed as a cytotoxic titre (Table 2). The cytotoxic titre of both A6 and $\mathrm{A} 6 \mathrm{H}$ was 1024 . The cytotoxic titre of A6A decreased to 8 , a 128-fold drop. The cytotoxic titre was eliminated at all dilutions in the A6HA double mutant. Both $\mathrm{A} 6 \mathrm{H}$ and $\mathrm{A} 6 \mathrm{~A}$ were still haemolytic on blood agar. However, inactivation of both toxin genes in the A6HA mutant completely abrogated haemolytic activity on blood agar plates.

\section{Distribution of the hlyA and aerA genes in Aeromonas isolates}

Primers $\mathrm{H} 1$ and $\mathrm{H} 2$ (Fig. 1) were used to determine whether a 597 bp blyA gene fragment was present in $A$. bydrophila strain Ah65. A similar survey was performed by PCR using primers A1 and A2 (Fig. 2) to determine whether a 416 bp aer $A$ gene fragment was detectable in A. hydrophila ATCC 7966. PCR results showed that the $597 \mathrm{bp}$ hlyA and $416 \mathrm{bp}$ aerA PCR products could be amplified from both strains (data not shown).

\section{DISCUSSION}

We report the mutagenesis of two distinct haemolysin genes for the first time in $A$. hydrophila. We suggest that the term HlyA be used to describe proteins which are homologous to the $V$. cholerae HlyA haemolysin and AerA for proteins homologous to aerolysin. Previously, terms such as haemolysin (Hirono \& Aoki, 1991, 1993; Hirono et al., 1992), aerolysin (Chakraborty et al., 1987; Howard et al., 1987) and cytolytic enterotoxin (Chopra et al., 1993) were often used sometimes interchangeably for proteins of this type (Table 3 ). The amino acid homology demonstrated by ASA1 $(66 \%)$ and AerA ( $77 \%$ ) to the A. hydrophila Ah65 aerolysin and by ASH4 $(75 \%)$ and AHH1 (85\%) to the A. hydrophila A6 HlyA haemolysin, the gene of which is clearly a distinct allele of the genes of these previously described toxins, lends support to the suggestion of Husslein et al. (1991) that both haemolytic toxins are a heterogeneous family of cytolytic haemolysins (Table 3). This diversity resembles that observed for the family of Shiga- and Shiga-like toxins of Shigella and enteroinvasive E. coli (Jackson, 1990).

The $h l y A$ and aer $A$ gene products are significantly different from one another at the amino acid level $(18 \%$ identity). A similar finding of two distinct haemolysin genes, ASH3 and ASH4, was also reported in a psychrophilic non-motile aeromonad, A. salmonicida 17-2 (Hirono \& Aoki, 1993). The ASH3 haemolysin was $66 \%$ homologous to the aerolysin of A. bydrophila Ah65 (Hirono \& Aoki, 1993), and is a homologue of AerA. The AHH1 and ASH4 haemolytic toxins had $50 \%$ and $45 \%$ (Hirono \& Aoki, 1993) homology, respectively, to the HlyA haemolysin of $V$. cholerae $\mathrm{O} 1$ biotype El Tor O17.

The HlyA haemolysin was shown to be homologous to AHH1, ASH4 and V. cholerae HlyA haemolytic toxins. However, using the criteria of von Heijne (1986), the published ORFs for AHH1 and ASH4 haemolytic toxins did not have putative signal peptides. Analysis of the potential protein coding region upstream from the ATG start codons of $\mathrm{AHH} 1$ and $\mathrm{ASH} 4$ showed that the residues responsible for the putative signal peptides are potentially encoded but are not found within the putative ORF, possibly as a result of frameshift. It is possible that a sequencing error was responsible for this observation and the apparent lack of signal peptides in ASH4 and AHH1. The extracellular location of these proteins, and the presence of a possible signal peptide in the A. hydrophila A6 HlyA reported here and for the $V$. cholerae HlyA (Alm et al., 1988; Yamamoto et al., 1990) provide evidence that this is a reasonable explanation.

The mechanism for the secretion of the A. hydrophila HlyA haemolysin across the outer membrane after its 
Table 3. Summary of published nomenclature and properties of $\boldsymbol{\beta}$-haemolytic toxins of Aeromonas spp.

\begin{tabular}{|c|c|c|c|c|}
\hline Gene/protein & Organism (source) & $\begin{array}{l}\text { Molecular } \\
\text { mass }(k D a)\end{array}$ & $\begin{array}{l}\text { Identity with other } \\
\text { proteins }\end{array}$ & Reference \\
\hline Aerolysin & $\begin{array}{l}\text { A. hydrophila Ah65 (rainbow trout } \\
\text { isolate) }\end{array}$ & $53 \cdot 8$ & Original aerolysin & Howard et al. (1987) \\
\hline AHH3 & A. bydrophila 28SA (eel isolate) & $54 \cdot 7$ & $94 \%$ identity with aerolysin & Hirono et al. (1992) \\
\hline AHH5 & A. hydrophila AH-1 (human isolate) & $53 \cdot 7$ & $92 \%$ identity with aerolysin & Hirono et al. (1992) \\
\hline $\begin{array}{l}\text { Cytolytic } \\
\text { enterotoxin }\end{array}$ & $\begin{array}{l}\text { A. bydrophila SSU (human } \\
\text { diarrhoeal isolate) }\end{array}$ & $54 \cdot 5$ & $93 \%$ identity with aerolysin & Chopra et al. (1993) \\
\hline ASA1 & A. sobria 33 (human isolate) & $53 \cdot 9$ & $66 \%$ identity with aerolysin & Hirono et al. (1992) \\
\hline $\operatorname{aer} A$ & $\begin{array}{l}\text { A. trota AB3 (human diarrhoeal } \\
\text { isolate) }\end{array}$ & $54 \cdot 4$ & $77 \%$ identity with aerolysin & Husslein et al. (1988) \\
\hline ASH3 & A. salmonicida $17-2$ (fish isolate) & $54 \cdot 2$ & $66 \%$ identity with aerolysin & Hirono \& Aoki (1993) \\
\hline AHH1 & $\begin{array}{l}\text { A. bydrophila ATCC } 7966 \text { (tinned } \\
\text { milk isolate) }\end{array}$ & $63 \cdot 6$ & $\begin{array}{l}50 \% \text { identity with V. cholerae } \\
\text { HlyA }\end{array}$ & Hirono \& Aoki (1991) \\
\hline HlyA & $\begin{array}{l}\text { A. hydrophila A6 (human } \\
\text { diarrhoeal isolate) }\end{array}$ & $69 \cdot 0$ & $\begin{array}{l}51 \% \text { identity with } V . \text { cholerae } \\
\text { HlyA }\end{array}$ & This study \\
\hline ASH4 & A. salmonicida $17-2$ (fish isolate) & $63 \cdot 4$ & $\begin{array}{l}45 \% \text { identity with } V . \text { cholerae } \\
\text { HlyA }\end{array}$ & Hirono \& Aoki (1993) \\
\hline
\end{tabular}

translocation across the bacterial inner membrane is unknown. Recently, the HlyA haemolysin of $V$. cholerae has been shown to have a single channel conductance, suggesting that this haemolysin has a channel-forming property (Menzl et al., 1996). It is probable by analogy that the A. bydrophila HlyA haemolysin is also a poreforming haemolysin.

In contrast to the behaviour of an analogous protein in $V$. cholerae, the $\mathrm{A} 6 \mathrm{H}$ mutant did not show attenuation in the suckling mouse model (Scheffe, $P>0.05$ ) nor did it show significant reduction in cytotoxic or haemolytic activity (Table 2). It has been reported that expression of the HlyA haemolysin in $V$. cholerae is regulated by an $11.9 \mathrm{kDa}$ protein designated HlyU (Williams et al., 1993). Insertional inactivation of the bly $U$ gene inhibited production of the HlyA haemolysin and a $28 \mathrm{kDa} \mathrm{Hcp}$ (haemolysin coregulated protein) protein. This increased the $\mathrm{LD}_{50}$ by 100 -fold in a suckling mouse model (Williams et al., 1996). The results would suggest that, in the suckling mouse model, the HlyA haemolysin is a more significant virulence factor in $V$. cholerae than the HlyA haemolysin is for A. hydrophila.

Inactivation of the aer $A$ gene resulted in a ninefold increase in $\mathrm{LD}_{50}$ in the suckling mouse model but the attenuation was not statistically significant (Scheffe, $P$ $>0.05)$. Statistically significant attenuation was attained only when both HlyA and AerA production was negated, resulting in a 20 -fold increase in $\mathrm{LD}_{50}$ (Scheffe, $P<0.05)$. The attenuation of virulence conferred by A6HA was also accompanied by complete loss of haemolytic and cytotoxic activities (Table 2). In addition, at $9 \mathrm{~h}$ post-inoculation, no fluid accumulation was observed in the gut of mice administered $48 \mathrm{LD}_{50}$ of the non- $\beta$-haemolytic double mutant (mean FA ratio $=$ $48 \mathrm{mg} \mathrm{g}^{-1}$ ) whilst mice administered the same dose of wild-type A6 had significant accumulation of fluid in the gut (mean FA ratio $=89 \mathrm{mg} \mathrm{g}^{-1}$ ). These results are similar to those of Stelma et al. (1986), who showed that culture filtrates of 19/21 $\beta$-haemolytic A. bydrophila isolates elicited fluid accumulation in permanently ligated rabbit ileal loops, whereas no fluid accumulation was shown in filtrates of eight non- $\beta$-haemolytic isolates. In contrast, inactivation of the aerolysin gene alone in Aeromonas trota abrogated both haemolytic and cytotoxic activity (Chakraborty et al., 1987). The A. trota mutant was attenuated $\left(\mathrm{LD}_{50}>10^{\circ}\right)$ in an intraperitoneal mouse model in comparison with the wildtype strain, which had an $\mathrm{LD}_{50}$ of $5 \times 10^{7}$. The cytolytic enterotoxin of $A$. bydrophila SSU, which is $93 \%$ homologous to the aerolysin of $A$. hydrophila Ah65, has also been shown to be lethal to mice after the toxin was injected intravenously (Chopra et al., 1993). These findings are consistent with the view that aeromonads are potential pathogens.

That reduction in virulence of the A6HA mutant, while significant, did not represent complete attenuation supports the notion that these gene products are major but not sole virulence factors. Other virulence-related factors such as pili (Atkinson \& Trust, 1980), haemagglutinins (Atkinson et al., 1987), lipopolysaccharide (Francki \& Chang, 1994) and outer-membrane proteins (Quinn et al., 1993) have been associated with virulence in aeromonads. The construction of multiple mutations for these factors and testing for further attenuation in the suckling mouse model would be a way of testing the relative contribution of these factors.

In A. hydrophila ATCC 7966 and A. hydrophila Ah65, both hly $A$ and aer $A$ genes were detected by PCR. For $A$. bydrophila ATCC 7966, in addition to the published bly $A$ allele already reported, the aerA gene was also 
detected. Similarly, for A. hydrophila Ah65, from which the aerolysin gene was cloned and sequenced, the bly $A$ gene was also detected by PCR. This supports the hypothesis that two toxins contribute to virulence in $A$. bydrophila and that the occurrence of the two toxin genes may be widespread in both clinical and environmental isolates within this species. A PCR survey for the detection of the $b l y A$ and aer $A$ toxin genes in other A. hydrophila isolates and Aeromonas isolates of other species is under way to determine their distribution and contribution to virulence in the suckling mouse model.

In conclusion, two haemolytic toxins are produced by $A$. bydrophila. Only when production of both HlyA and Aer A was inactivated by mutagenesis was both cytotoxic and haemolytic activity eliminated and statistically significant but not total attenuation observed. Both haemolytic toxins contribute to virulence but factors other than haemolytic toxins contribute to virulence of A. bydrophila.

\section{ACKNOWLEDGEMENTS}

This project was supported by the University of South Australia, School of Pharmacy and Medical Sciences Research Fund. We thank the IMVS for allowing the use of reagents and equipment for performing the molecular biology experiments and Clive and Vera Ramaciotti Foundations for the purchase of the Corbett thermal sequencer. We also wish to thank Phillip Leppard for his statistical consultation (Department of Statistics, University of Adelaide).

\section{REFERENCES}

Agger, W. A., McCormick, J. D. \& Gurwith, M. J. (1985). Clinical and microbiological features of Aeromonas bydrophilaassociated diarrhoea. J Clin Microbiol 21, 909-913.

Alm, R. A., Stroeher, U. H. \& Manning, P. A. (1988). Extracellular proteins of Vibrio cholerae: nucleotide sequence of the structural gene $(b l y \mathrm{~A})$ for the haemolysin of the haemolytic El Tor strain $\mathrm{O} 17$ and characterization of the hly A mutation in the nonhaemolytic classical strain 569B. Mol Microbiol 2, 481-488.

Alonso, J. L., Botella, M. S., Amoros, I. \& Alonso, M. A. (1994). The occurrence of mesophilic aeromonad species in marine recreational waters of Valencia (Spain). J Environ Sci Health 29, $615-628$.

Atkinson, H. M. \& Trust, T. J. (1980). Hemagglutination properties and adherence ability of Aeromonas hydrophila. Infect Immun 27, 938-946.

Atkinson, H. M., Adams, D., Savvas, R. S. \& Trust, T. J. (1987). Aeromonas adhesin antigens. Experientia 43, 372-374.

Burke, V., Gracey, M., Robinson, J., Pesek, D., Beaman, J. \& Bundell, C. (1983). The microbiology of childhood gastroenteritis : Aeromonas species and other infective agents. J Infect Dis 148, 68-74.

Chakraborty, T., Huhle, B., Hof, H., Bergbauer, H. \& Goebel, W. (1987). Marker exchange mutagenesis of the aerolysin determinant in Aeromonas bydrophila demonstrates the role of aerolysin in A. bydrophila-associated systemic infections. Infect Immun 55, 2274-2280.

Chopra, A. K., Houston, C. W., Peterson, J. W. \& Jin, G.-F. (1993). Cloning, expression, and sequence analysis of a cytolytic entero- toxin gene from Aeromonas bydrophila. Can J Microbiol 39, 513-523.

Delamorena, M. L., Van, R., Singh, K., Brian, M., Murray, B. E. \& Pickering, L. K. (1993). Diarrhea associated with Aeromonas species in children in day care centers. J Infect Dis 168, 215-218.

Deodhar, L. P., Saraswathi, K. \& Varudkar, A. (1991). Aeromonas spp. and their association with human diarrheal disease. $J$ Clin Microbiol 29, 853-856.

Francki, K. T. \& Chang, B. J. (1994). Variable expression of Oantigen and the role of lipopolysaccharide as an adhesin in Aeromonas sobria. FEMS Microbiol Lett 122, 97-102.

von Heijne, G. (1986). A new method for predicting signal sequence cleavage sites. Nucleic Acids Res 14, 4683-4690.

Hirono, I. \& Aoki, T. (1991). Nucleotide sequence and expression of an extracellular hemolysin gene of Aeromonas bydrophila. Microb Pathog 11, 189-197.

Hirono, I. \& Aoki, T. (1993). Cloning and characterization of 3 hemolysin genes from Aeromonas salmonicida. Microb Pathog 15, 269-282.

Hirono, I., Aoki, T., Asao, T. \& Kozaki, S. (1992). Nucleotide sequences and characterization of haemolysin genes from Aeromonas hydrophila and Aeromonas sobria. Microb Pathog 13, 433-446.

Hohn, B. \& Collins, J. (1980). A small cosmid for efficient cloning of large DNA fragments. Gene 11, 291-298.

Howard, S. P., Garland, W. J., Green, M. J. \& Buckley, J. T. (1987). Nucleotide sequence of the gene for the hole-forming toxin aerolysin of Aeromonas hydrophila. J Bacteriol 169, 2869-2871.

Husslein, V., Huhle, B., Jarchau, T., Lurz, R., Boebel, W. \& Chakraborty, T. (1988). Nucleotide sequence and transcriptional analysis of the aerCaerA region of Aeromonas sobria encoding aerolysin and its regulatory region. Mol Microbiol 2, 507-517.

Husslein, V., Bergbauer, H. \& Chakraborty, T. (1991). Studies on aerolysin and serine protease from Aeromonas trota sp. nov. Experientia 47, 420-421.

Jackson, M. P. (1990). Structure-function analyses of Shiga toxin and Shiga-like toxins. Microb Pathog 8, 235-242.

Matthews, N. \& Neale, M. L. (1987). Cytotoxicity assays for tumour necrosis factor and lymphotoxin. In Lymphokines and Interferons, a Practical Approach, pp. 221-225. Edited by M. J. Clements, A. G. Morris \& A. J. H. Ghearing. Oxford: IRL Press.

Menard, R., Sansonetti, P. \& Parsot, C. (1993). Non-polar mutagenesis of the ipa genes defines IpaB, IpaC, and IpaD as effectors of Shigella flexneri entry into epithelial cells. J Bacteriol 175, 5899-5906.

Menzl, K., Maier, E., Chakraborty, T. \& Benz, R. (1996). HlyA hemolysin of Vibrio cholerae O1 biotype El Tor. Identification of the hemolytic complex and evidence for the formation of anionselective ion-permeable channels. Eur J Biochem 240, 646-654.

Miller, J. (1972). Experiments in Molecular Genetics. Cold Spring Harbor, NY: Cold Spring Harbor Laboratory.

Ogunsanya, T. I., Rotimi, V. O. \& Adenuga, A. (1994). A study of the aetiological agents of childhood diarrhoea in Lagos, Nigeria. J Med Microbiol 40, 10-14.

Okpokwasili, G. C. (1991). Aeromonas hydrophila: variability in biochemical characteristics of environmental isolates. J Basic Microbiol 31, 177-188.

Papapetropoulou, M. \& Rodopoulou, G. (1994). Occurrence of enteric and non-enteric indicators in coastal waters of Southern Greece. Bull Mar Sci 54, 63-70.

Parker, M. W., Buckley, J. T., Postma, J. P. M., Tucker, A. D., 
Leonard, K., Pattus, F. \& Tsernoglou, D. (1994). Structure of the Aeromonas toxin proaerolysin in its water soluble and membrane-channel states. Nature 367, 292-295.

Parker, M. W., van der Goot, F. G. \& Buckley, J. T. (1996). Aerolysin - the ins and outs of a model channel-forming toxin. Mol Microbiol 19, 205-212.

Quinn, D. M., Wong, C. Y. F., Atkinson, H. M. \& Flower, R. L. P. (1993). Isolation of carbohydrate-reactive outer membrane proteins of Aeromonas bydrophila. Infect Immun 61, 371-377.

Rautelin, H., Hănnien, M. L., Sivonen, A., Turunen, U. \& Valtonen, v. (1995). Chronic diarrhea due to a single strain of Aeromonas caviae. Eur J Clin Microbiol Infect Dis 14, 51-53.

Rhodes, M. W. \& Kator, H. (1994). Seasonal occurrence of mesophilic Aeromonas spp. as a function of biotype and water quality in temperate freshwater lakes. Water Res 28, 2241-2251.

Rose, J. M., Houston, C. W. \& Kurowsky, A. (1989). Bioactivity and immunological characterisation of a cholera toxin-crossreactive cytolytic enterotoxin from Aeromonas hydrophila. Infect Immun 57, 1170-1176.

Shine, J. \& Dalgarno, L. (1974). The $3^{\prime}$ terminal sequence of Escherichia coli $16 \mathrm{~S}$ ribosomal RNA: complementary to ribosomal binding sites. Proc Natl Acad Sci USA 71, 1342-1346.

Southern, E. M. (1975). Detection of specific sequences among DNA fragments separated by gel electrophoresis. J Mol Biol 98, 503-517.

Stelma, J. G. N., Johnson, C. H. \& Spaulding, P. (1986). Evidence for the direct involvement of $\beta$-hemolysin in Aeromonas bydrophila enteropathogenicity. Curr Microbiol 14, 71-77.

Sugita, H., Tanaka, K., Yoshinami, M. \& Deguchi, Y. (1995).
Distribution of Aeromonas species in the intestinal tracts of river fish. Appl Environ Microbiol 61, 4128-4130.

Utsalo, S. J., Eko, F. O., Antia-Obong, O. E. \& Nwaigwe, C. U. (1995). Aeromonads in acute diarrhoea and asymptomatic infections in Nigerian children. Eur J Epidemiol 11, 171-175.

Williams, S. G., Attridge, S. R. \& Manning, P. A. (1993). The transcriptional activator HlyU of Vibrio cholerae: nucleotide sequence and role in virulence gene expression. Mol Microbiol 9, 751-760.

Williams, S. G., Varcoe, L. T., Attridge, S. R. \& Manning, P. A. (1996). Vibrio cholerae Hcp, a secreted protein coregulated with HlyA. Infect Immun 64, 283-289.

Wong, C. Y. F., Mayrhofer, G., Heuzenroeder, M. W., Atkinson, H. M., Quinn, D. M. \& Flower, R. L. P. (1996). Measurement of virulence of aeromonads using a suckling mouse model of infection. FEMS Immunol Med Microbiol 15, 233-241.

Wong, C. Y. F., Heuzenroeder, M. W. \& Flower, R. L. P. (1997). Cloning and characterization of two immunophilin-like genes, ilp $A$ and $f k p A$, on a single 3.9-kilobase fragment of Aeromonas bydrophila genomic DNA. J Bacteriol 179, 3397-3403.

Yamamoto, K., Ichinose, Y., Shinagawa, H., Makino, K., Nakata, A., Iwanaga, M., Honda, T. \& Miwatani, T. (1990). Two-step processing for activation of the cytolysin/hemolysin of Vibrio cholerae $\mathrm{O} 1$ biotype $\mathrm{EI}$ Tor: nucleotide sequence of the structural gene ( $h l y \mathrm{~A})$ and characterization of the processed products. Infect Immun 58, 4106-4116.

Received 21 May 1997; revised 30 September 1997; accepted 23 October 1997. 